\title{
ELAMENOPSIS GUINOTAE, A NEW SPIDER CRAB FROM BASS STRAIT, AUSTRALIA (BRACHYURA, HYMENOSOMATIDAE)
}

\author{
BY \\ GARY C. B. POORE ${ }^{1}$ ) \\ Museum Victoria, GPO Box 666, Melbourne, Victoria 3001, Australia
}

\begin{abstract}
Elamenopsis guinotae sp. nov. is described from a temperate shallow sandy environment in Bass Strait, Australia. The new species is most similar to E. rotunda, one of four other species in the genus, all from the tropical western Pacific. The two species share a subcircular carapace with the carapace rim width about 1.2 times as wide as long, and long, slender walking legs. It differs in the absence of an anterolateral notch on the carapace and the broader female abdomen. Features differentiating all five species of Elamenopsis are tabulated.
\end{abstract}

\section{RÉSUMÉ}

Elamenopsis guinotae sp. nov. est décrite du Détroit de Bass, dans un environnement d'eaux tempérées, peu profondes et de fonds sableux. La nouvelle espèce est très similaire à $E$. rotunda, l'une des quatre autres espèces du genre, toutes du Pacifique ouest. Les deux espèces ont en commun une carapace semi-circulaire, 1,2 fois plus large que longue et des pattes marcheuses longues et fines. Cette nouvelle espèce se différencie par l'absence d'une encoche antérolatérale sur la carapace et un abdomen femelle plus large. Les caractères séparants des cinq espèces d'Elamenopsis sont comparés.

\section{INTRODUCTION}

The soft sediment fauna of eastern Bass Strait has a notably high diversity (Coleman et al., 1997) and features many apparently rare (narrowly distributed or rarely caught) species among the more than 800 documented species. The decapods of this area are now well documented (Poore, 2004) and, of the known fauna, only a single species of hymenosomatid crab remains

\footnotetext{
1) e-mail: gpoore@museum.vic.gov.au 
undescribed (Poore, 2004). The species was featured in O'Hara's (2002) discussion of endemism, rarity, and vulnerability along a temperate coastline of Australia because it is represented by few individuals taken from four grab samples along a $25 \mathrm{~km}$ long 14-15 metre depth contour. The species, which was then incorrectly referred to the genus Halicarcinus White, 1846 is described here as a new species of Elamenopsis A. Milne-Edwards, 1873.

Hymenosomatid spider crabs are represented in Australia by 30 species (Lucas, 1980; Davie, 2002). In the Bass Strait region between Victoria and Tasmania four species are known thus far: Halicarcinus ovatus Stimpson, 1859, H. rostratus (Haswell, 1881), Hymenosoma hodgkini Lucas, 1980, and Trigonoplax longirostris McCulloch, 1908 (cf. Poore, 2004).

The diagnosis of the new species is based on the characters in Naruse \& Ng's (2007) key to species of Elamenopsis. Type material is lodged in Museum Victoria, Melbourne (NMV) and the Queensland Museum, Brisbane (QM). Three dimensions are given: carapace length along the median line from the rostrum to the posterior margin (cl); carapace width measured at its widest point $(\mathrm{cw})$; and carapace rim width (often the only measurement available from comparative illustrations) measured transversely at the widest point of the dorsal rim (crw).

Elamenopsis A. Milne-Edwards, 1873

Remarks. - Elamenopsis was diagnosed and discussed by Naruse \& Ng (2007). The genus comprises only four species, all from the western Pacific: E. lineata A. Milne-Edwards, 1873 from New Caledonia, the Philippines, Sulawesi, Singapore, and north-eastern Australia (Ng \& Richer de Forges, 1996), E. ariakensis (Sakai, 1969) from Japan and China (Kosuge et al., 2002), E. comosa $\mathrm{Ng} \&$ Chuang, 1996 from Indonesia, and E. rotunda Naruse \& Ng, 2007 from Singapore. Naruse \& Ng (2007) compared them all and provided a key. The new species described here extends the range of the genus into temperate southern Australia.

Elamenopsis guinotae sp. nov. (figs. 1, 2)

Material examined. - Holotype: Australia, Victoria, Bass Strait, $1 \mathrm{~km}$ off Woodside Beach (38 $33^{\prime} \mathrm{S} 146^{\circ} 57^{\prime} \mathrm{E}$ ), $15 \mathrm{~m}, 08$ Mar. 1989 (stn MSL-LV 2W4), NMV J59277 (female, cl $2.16 \mathrm{~mm}$, cw $2.95 \mathrm{~mm})$.

Paratypes (many lacking some or all ambulatory legs): collected with holotype, NMV J31879 (3 males, cw $1.6 \mathrm{~mm}$ ); QM W28877 (male, cw $1.6 \mathrm{~mm}$; female, $1.7 \mathrm{~mm}$ ). One (1) km off Woodside Beach ( $\left.38^{\circ} 33^{\prime} \mathrm{S} 146^{\circ} 57^{\prime} \mathrm{E}\right), 14.5 \mathrm{~m}, 08$ Mar. 1989 (stn MSL-LV 1W5), NMV J31881 (juvenile male, cw 1.6 mm); (stn MSL-LV 2W5), NMV J31878 (6 juvenile males, cw 
$1.2 \mathrm{~mm} ; 2$ females, cw $1.6 \mathrm{~mm}$ ), NMV J59646 (male, cw $2.0 \mathrm{~mm}$ ). One (1) km off Delray Beach ( $38^{\circ} 14^{\prime} \mathrm{S} 147^{\circ} 22^{\prime} \mathrm{E}$ ), $14.8 \mathrm{~m}, 24$ Mar. 1989 (stn MSL-LV 3T3), NMV J31880 (female, cw $3.0 \mathrm{~mm})$.

Diagnosis. - Carapace ovoid, flat or barely convex, widest at about threequarters length, $\mathrm{cw}: \mathrm{cl}$ ratio of adult female 1.36, crw : cl ratio of adult female 1.21; anterolateral margin evenly curved; subhepatic region broadly swollen; rostrum triangular in anterior view, with lateral ridges, bilobed in dorsal view; maxilliped 3 ischium mesial margin 3 times as long as merus mesial margin; ambulatory legs slender (merus of third leg 4.3 times as long as wide), long (length of third leg 1.5 times $\mathrm{cw}$ ); male abdomen 6-segmented, uropods prominent; gonopod 1 stout, spindle-shaped, 4 times as long as greatest thickness, tapering distally.

Description. - Female (cw $2.95 \mathrm{~mm}$ ). Carapace (fig. 1a) ovoid, widest at about three-quarters length, $\mathrm{cw}: \mathrm{cl}$ ratio of adult female 1.35 , crw : cl ratio of adult female 1.2; lateral surfaces around bases of second and third legs expanded laterally; dorsally flat or barely convex, dorsal rim without angles, regions well defined; cervical groove branching anteriorly to weakly defined hepatic region, connected posteriorly with gastro-cardiac and thoracic grooves, thoracic groove connecting to cardiac-intestinal groove, branchial region divided by weak oblique-transverse groove into pre- and post-branchial regions, intestinal region with weak median groove. Rostrum triangular, apically bifid in dorsal view, strongly deflexed, with prominent lateral ridges not confluent with dorsal rim but running over orbit. Subhepatic region swollen in upper half, with weakly curved ridge defining lateral margin of orbit; with slight boss mesially under orbit. Dorsal rim, lateral margins of carapace with scattered short, stout setae. Epistome (fig. 1b) with sharp medial anterior projection, not separating antennules, with rounded posterior projection. Eyestalk short, dilating; cornea rounded, visible in dorsal view. Maxilliped 3 (fig. 2e) meri covering 0.6 of width of mouthfield, leaving wide gape when closed; ischium triangular, mesial margin 3 times as long as merus mesial margin; merus ovoid, 1.2 times as long as wide; ischium, merus with row of long mesial setae; exopod base 3.8 times as long as wide, distal end not reaching distal outer angle of merus, flagellum about one-third length of base.

Chelipeds (fig. 1d, e) unequal, with setose outer surfaces; propodus oval in cross-section, deepest near midpoint, total length 2.1 times depth in larger cheliped, 2.4 times in smaller cheliped; propodus-dactylus articulation oblique; cutting edges of fixed finger, dactylus unevenly dentate; dactylus 0.55 times total propodus length, 3.0 times as long as wide in larger cheliped, 3.6 times as long as wide in smaller cheliped. 


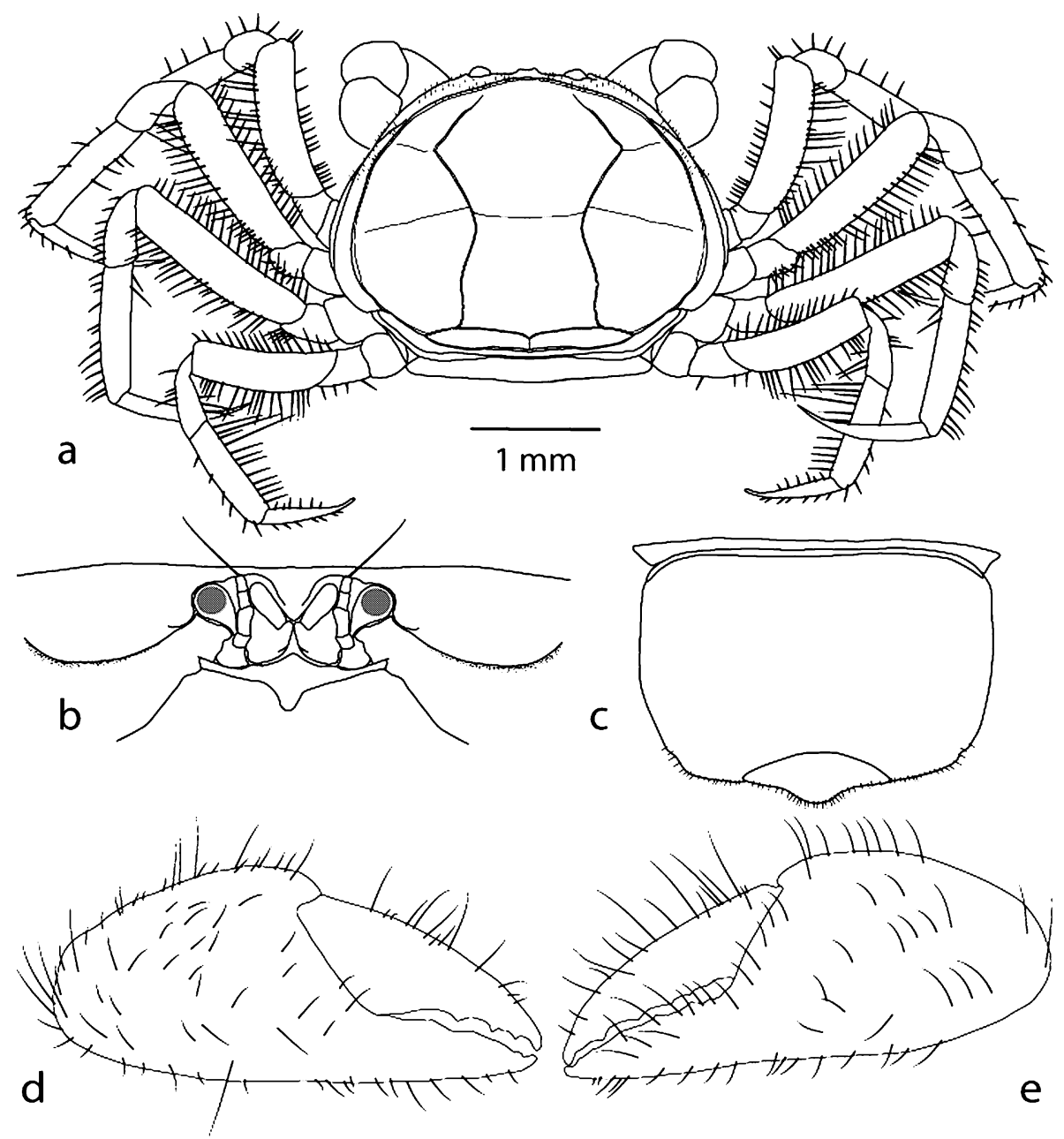

Fig. 1. Elamenopsis guinotae sp. nov., female holotype. a, habitus; b, front; c, abdomen; $\mathrm{d}$, e, face views of right and left chelipeds. Scale bar refers to fig. 1a only.

Ambulatory legs (fig. 2f) long, second leg the longest (third leg 1.5 times as long as cw, 1.7 times as long as crw), slender (merus of third leg 4.3 times as long as wide), flattened, flexor, extensor margins of meri densely fringed with long setae, carpus-dactylus with fewer setae scattered over all faces, dactylus about as long as propodus, evenly tapering, curved.

Abdomen (fig. 1c) with 2 short free somites, fused somites 3-5 are 1.6 times as wide as long, with lateral margins strongly converging distally, somites not evident laterally; telson free, width 0.4 abdomen width. Pleopods 1-4 biramous. 

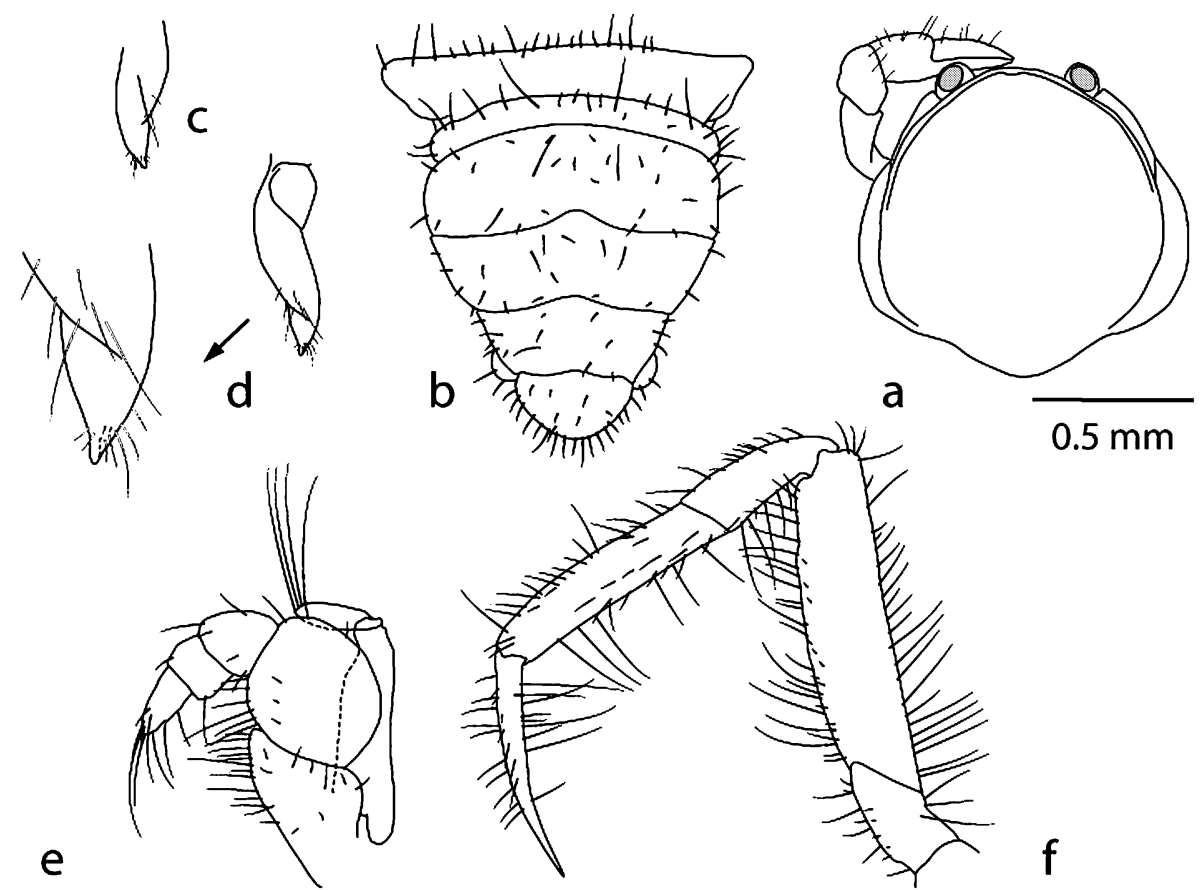

Fig. 2. Elamenopsis guinotae sp. nov.: a, juvenile male NMV J31878. b-d, adult male NMV J59646: b, abdomen; c, gonopod 1 (posterior view); d, gonopod 1 (anterior view and detail). e, female, NMV J31880: maxilliped 3; f, female holotype: walking leg 3. Scale bar refers to fig. 2a only; abdomen and gonopod 1 to same scale.

Male (cw $2.00 \mathrm{~mm}$ ). - Abdomen (fig. 2b) 6-segmented, 1.06 times as long as greatest width, third somite widest, fifth somite with prominent uropods. Gonopod 1 (fig. 2c, d) stout, spindle-shaped, 4 times as long as greatest thickness, twisting, tapering distally, with 6 distal setae along anterior ridge, 7 setae plus setules on triangular apex.

Juvenile male (cw $1.2 \mathrm{~mm}$ ). - Carapace (fig. 2a) narrower than in adults, subcircular, $\mathrm{cw}: \mathrm{cl}=1.1$, crw $: \mathrm{cl}=0.95$.

Distribution. - Australia, Victoria, eastern Bass Strait, 14-15 m depth, coarse sandy-shelly sediments.

Etymology. - The species name recognizes the lifetime of insightful contributions to the systematics of brachyuran crabs by Danièle Guinot, and her friendship.

Remarks. - Elamenopsis guinotae sp. nov. is most similar to E. rotunda, sharing a subcircular carapace with the carapace rim width about 1.2 times as wide as long, and long, slender walking legs (table I). It differs in the absence of an anterolateral notch on the carapace and the broader female abdomen. 
TABLE I

Comparison of the five species of Elamenopsis (? indicates unknown)

\begin{tabular}{|c|c|c|c|c|c|}
\hline & $\begin{array}{c}\text { E. lineata } \\
\text { A. Milne- } \\
\text { Edwards, } 1873\end{array}$ & $\begin{array}{c}\text { E. comosa } \\
\text { Ng \& Chuang, } \\
1996\end{array}$ & $\begin{array}{l}\text { E. ariakensis } \\
\text { (Sakai, 1969) }\end{array}$ & $\begin{array}{c}\text { E. rotunda } \\
\text { Naruse \& Ng, } \\
2007\end{array}$ & $\begin{array}{l}\text { E. guinotae } \\
\text { sp. nov. }\end{array}$ \\
\hline Distribution & $\begin{array}{l}\text { New Caledonia, } \\
\text { Philippines, } \\
\text { Sulawesi, } \\
\text { Singapore, } \\
\text { north-eastern } \\
\text { Australia }\end{array}$ & Indonesia & Japan, China & Singapore & $\begin{array}{c}\text { SE } \\
\text { Australia }\end{array}$ \\
\hline crw : cl & 1.3 & 1.4 & 1.2 & 1.2 & 1.2 \\
\hline Gastric region & smooth & smooth & with 3 tubercles & smooth & smooth \\
\hline $\begin{array}{l}\text { Anterolateral notch } \\
\text { on carapace }\end{array}$ & absent & absent & present & present & absent \\
\hline $\begin{array}{l}\text { Maxilliped } 3 \text { merus } \\
\text { inner margin }\end{array}$ & $\begin{array}{l}\text { equal to } \\
\text { ischium }\end{array}$ & $\begin{array}{l}\text { longer than } \\
\text { ischium }\end{array}$ & $\begin{array}{l}\text { longer than } \\
\text { ischium }\end{array}$ & $\begin{array}{l}\text { shorter than } \\
\text { ischium }\end{array}$ & $\begin{array}{l}\text { shorter than } \\
\text { ischium }\end{array}$ \\
\hline $\begin{array}{l}\text { Walking leg } 3 \\
\text { length : crw }\end{array}$ & 1.2 & $?$ & 1.3 & 1.6 & 1.7 \\
\hline $\begin{array}{l}\text { Walking leg } 3 \\
\text { merus length : } \\
\text { width }\end{array}$ & 3 & $?$ & 3 & 4.0 & 4.3 \\
\hline $\begin{array}{l}\text { Male abdominal } \\
\text { somites }\end{array}$ & $\begin{array}{l}5 \text { (somites } 4 \\
\text { and } 5 \text { fused) }\end{array}$ & 6 & $\begin{array}{l}4 \text { (somites } \\
3-5 \text { fused) }\end{array}$ & $?$ & 6 \\
\hline Uropods & absent & absent & absent & $?$ & present \\
\hline Male gonopod 1 & $\begin{array}{l}\text { slender, } \\
\text { tapering, } \\
\text { twisted }\end{array}$ & $\begin{array}{l}\text { slender, } \\
\text { apex sharp- } \\
\text { ly curved }\end{array}$ & $\begin{array}{l}\text { slender, tapering, } \\
\text { evenly curved, } \\
\text { twisted }\end{array}$ & $?$ & $\begin{array}{l}\text { stout, apex } \\
\text { not curved }\end{array}$ \\
\hline $\begin{array}{l}\text { Female fused } \\
\text { abdomen somites } \\
\text { width : length }\end{array}$ & 1.2 & 1.0 & $?$ & 1.2 & 1.6 \\
\hline $\begin{array}{l}\text { Female abdominal } \\
\text { segmentation }\end{array}$ & $\begin{array}{r}\text { laterally } \\
\text { evident }\end{array}$ & $\begin{array}{r}\text { laterally } \\
\text { evident }\end{array}$ & $?$ & not evident & not evident \\
\hline
\end{tabular}

The male of E. rotunda is unknown. In E. ariakensis, a third species with a subcircular carapace, there is a median notch on the dorsal rim and swellings on each side; the hepatic region has a clear notch and the gastric region has three tubercles; maxilliped 3 has a longer merus; the male abdominal somites 3-5 are fused and the gonopod 1 is slender. The other two species, $E$. lineata and $E$. comosa, have a broader carapace, stouter walking legs (at least in E. lineata), and the somites of the female abdomen are laterally indicated (table I).

No author has previously reported on female pleopods in species of Elamenopsis. The new species has four pairs of biramous pleopods. Uropods, 
present in this species as lateral protrusions on the penultimate abdominal somite of the male, have not been illustrated for the three species where males are known (table I).

Elamenopsis lineata has been reported from estuaries in Indonesia and Queensland, Australia (Ng \& Chuang, 1996), E. rotunda from sublittoral mudflats off Singapore, and E. ariakensis from a mudflat off Nagasaki, Japan, commensal with a common holothurian, Protankyra bidentata (Woodward \& Barrett, 1858). In contrast to these tropical and muddy shallow environments, the new species, Elamenopsis guinotae, is known from a temperate shelf environment with coarse sandy-shelly sediments. No associates are known.

\section{ACKNOWLEDGEMENTS}

I thank the organizers of this volume, Bertrand Richer de Forges, Peter Castro, Peter J. F. Davie, and Peter K. L. Ng, for the invitation to contribute. I thank Peter $\mathrm{Ng}$ for comments on a first draft of the manuscript, the late Noel Coleman of the Victorian Marine and Freshwater Research Institute, Queenscliff, for the opportunity to examine the collections from eastern Bass Strait, and Helen Lew Ton for much of the sorting and preliminary identifications.

\section{REFERENCES}

Coleman, N., A. S. H. Gason \& G. C. B. Poore, 1997. High species richness in the shallow marine waters of south-east Australia. Marine Ecology Progress Series, 154: 1726.

DAvie, P. J. F., 2002. Crustacea: Malacostraca: Eucarida (Part 2): Decapoda - Anomura, Brachyura: i-xiv, 1-641. (CSIRO Publishing, Melbourne).

Haswell, W. A., 1881. On some new Australian Brachyura. Proceedings of the Linnean Society of New South Wales, 6: 540-551.

Kosuge, I., Y. Koshishi \& N. Suyama, 2002. Rediscovery of Elamenopsis ariakensis (Brachyura, Hymenosomatidae) from Ariake-kai Sound, Kyushu, western Japan. Nankiseibutsu, 44: 103-105. [In Japanese with English summary.]

LUCAS, J. S., 1980. Spider crabs of the family Hymenosomatidae (Crustacea; Brachyura) with particular reference to Australian species: systematics and biology. Records of the Australian Museum, 33: 148-247.

MCCulloch, A. R., 1908. Studies in Australian Crustacea. No. 1. Records of the Australian Museum, 7: 51-59, pl. 12.

Milne-EdWARDS, A., 1873. Recherches sur la faune carcinologique de la NouvelleCalédonie. Nouvelles Archives du Muséum d'Histoire Naturelle, Paris, 9: 155-322, pls. 418. 
NARUSE, T. \& P. K. L. NG, 2007. On a new species of Elamenopsis from Singapore, with notes on Crustaenia palwanensis (Sèrene, 1971) (Crustacea: Decapoda: Brachyura: Hymenosomatidae). Raffles Bulletin of Zoology, 55: 121-125.

NG, P. K. L. \& C. T. N. ChuAnG, 1996. The Hymenosomatidae (Crustacea: Decapoda: Brachyura) of southeast Asia, with notes on other species. Raffles Bulletin of Zoology, (Supplement) 3: 1-82.

NG, P. K. L. \& B. RicheR DE Forges, 1996. The Hymenosomatidae (Crustacea: Decapoda: Brachyura) of New Caledonia, with descriptions of two new genera and two new species. Memoirs of the Queensland Museum, 39: 263-276.

O'HARA, T. D., 2002. Endemism, rarity and vulnerability of marine species along a temperate coastline. Invertebrate Systematics, 16: 671-684.

Poore, G. C. B., 2004. Marine decapod Crustacea of southern Australia. A guide to identification (with chapter on Stomatopoda by Shane Ahyong): 1-574. (CSIRO Publishing, Melbourne).

SAKAI, T., 1969. Two new genera and twenty-two new species of crabs from Japan. Proceedings of the Biological Society of Washington, 82: 243-280.

STIMPSON, W., 1859. Prodromus descriptionis animalium evertebratorum, quae in expeditione ad Oceanum Pacificum septentrionalem, a Republica Federata missa, Cadwaladaro Ringgold et Johanne Rodgers ducibus, observavit et descripsit. Pars VII. Crustacea Anomura. Proceedings of the Academy of Natural Science of Philadelphia, 1858: 225-251.

White, A., 1846. Notes on four new genera of Crustacea. Annals and Magazine of Natural History, (1) 18: 176-178, pl. 2.

First received 23 February 2009.

Final version accepted 8 May 2009. 